\title{
Treaty of Waitangi
}

\section{Xuefei Wang}

\section{INTRODUCTION}

Treaty of Waitangi is such a controversial document in New Zealand that it stands in the center of the stage of New Zealand history from 1840s. While the treaty has resulted in a number of significant longstanding grievances, especially from Maoris, it also protects Maori people in some extent. It is strange that a document which protects Maoris from extinction is resisted by Maori People.

Everyone knows that New Zealand is a bicultural society which means that there are two dominant cultures here. One is Pakeha culture "dominant by power, history, and majority", which refers to the culture of the New Zealand Europeans. The other one is Maori culture "dominant by a longer history, by legacy and by its strength of survival and the passionate commitment of its people" (James Ritchie, 1992:6). In the meantime, New Zealand, as an immigrant country, is a multicultural society. Thus it seems hard for New Zealand people to reach an agreement in terms of identity on a singular basis (James $\mathrm{H}$ et al., 2005:11). Just like the Indians in America, Maori people hold that this is their homeland. In spite of the fact that Maori people and their life are influenced by the other culture in the process of contact with Europeans, Maori people today still keep their own tradition in life and their culture plays an important place in New Zealand society. Compare with American Indians, they are much luckier. Treaty of Waitangi stipulates that Maoris' tradition, custom, homeland and possession should be protected.

\section{THE CLASHES BETWEEN THE TWO PEOPLES IN HISTORY}

Maori people had been living in New Zealand for at least 800 years before the first European ships came to New Zealand in 1642. Abel Tasman is the first European who came across Maori. Unfortunately, his crew failed to communicate with Maori, which result in the bloody conflict. Not until 1769 did British explorer, James Cook, establish friendly relations with some Maori. In the 1790s, according to captain James Cooker's experiences, Europeans established semipermanent contact successfully with the Tangata Whenua (indigenous people) in te Ika-AMaui(North Island of New Zealand)'S Bay Of Islands. (Erik Olssen and Michael P.J. Reilly, 2004:140). Gradually, New Zealand was known for the rich local resources so that more and more Europeans whalers and sealers were drawn to come to New Zealand.

The Europeans were well aware that it was inevitable for them to keep in contact with Maori, as they need "local knowledge, food, resources, companionship, labor and, most important of all, guarantees the newcomers' safety". (The History Group of the New Zealand Ministry for Culture and Heritage, 19 Sep. 2014). At the same time, Maori people also found the enormous economic benefits from cooperating with Europeans. Both sides realized that they would have an advantage of communicating each other. As a result of this common consensus, many European vessels absorbed young Maori men, and meanwhile some European men incorporate into Maori kinship structures through marriage with Maori women. 
Out of curiosity, some Maori went to Eurasia for a visit, which brought back to New Zealand new ideas and concepts. The Maori with such experiences to Europe had made great contribution to the preservation of Maori culture. They introduced to Maori literacy by translating parts of Bible. (The History Group of the New Zealand Ministry for Culture and Heritage, 1 Fed. 2017). Thanks to their efforts, Maori language can exist and develop well.

The cross-culture communication will not run smoothly without a hitch. Certainly, conflicts also arose during early contacts between the two worlds.

In the physical aspect, Europeans brought to New Zealand germs to which Maoris have no immunities. Consequently, a great number of people got affected and died, and the population of Maoris reduced sharply.

Most conflicts can be found in the differences between their views. Before explorers found this land, Maori has shaped their own world-view which is quite different from that of European. Firstly, creative myths influence their world-view deeply. According to the Maori myths, the world was created by Io who enclosed everything within its own existence. Alternatively, their god is called "atua" who create the human beings. The tribe kinship system was from the creation genealogy of Io myth. (Michael P. J. Reilly, 2004:11-12). Secondly, the world-view differences also embody how to mark the locations. For Pākehā, New Zealand is composed of North Island and South Island, which is defined with maps and geographical markers. However, for Maori, "Te Ika-a-Māui"(North Island) means the fish of Māui and "Te Wai Pounamu" or "Te Wāhi Pounamu"(South Island) means the water of greenstone or the place of greenstone (Tānia and Rawinia, 2004:20-21). Thirdly, "Acceptance of trade and European practices were to be on Maori terms, and concepts of utu and mana were central to this."(The History Group of the New Zealand Ministry for Culture and Heritage, 20 Dec. 2012 ). Mana means "a term closely linked to the concept of tapu used to refer to authority, power, control, influence and prestige in relation to atua, people, land and the environment".(Tania and Rawinia, 2004:17). Utu often used as "revenge". Accurately, this kind of revenge refers to keep a balance when the mana or tapu is challenged. (Tania and Rawinia 18) Lastly, as savages, Maori also have Cannibalism custom which cannot be accepted by Europeans.

Differences in world-views and traditions also brought about sharp clashes between Pakeha and Maori. For instance many incidents took place especially in the frontier, including the burning of the Boyd (1809), the Elizabeth incident (1830), the Harriet affair (1834) and the 'hell-hole'. Muskets were used to attack Maori tribe. (The History Group of the New Zealand Ministry for Culture and Heritage, 5 Aug. 2014). It's strange that the conflicts in the frontier did not estrange the relation between Maoris and Europeans, but rather enhanced their contacts. As a result, the Europeans had come to take over the affairs and New Zealand was on the way to become the colony of Britain Empire.

In 1788, The Colonial Office in London's Whitehall which was the hub of the British Empire decided to found the penal colony in New South Wales in Australia. By the 1830s, Sydney, the most famous city in New South Wales, had been a large and prosperous post full of businessmen and commercial community who had strong interests in the Pacific and New Zealand. So New South Wales government and Britain government recognize that New Zealand should be controlled by the official authority.

In May 1833, James Busby arrived at Bay of Islands as a representative of British government. However, he has no real power. At that time, Maori society had their own system of authority and regulations, but Busty tried to incorporate them with the western style. In 1835, he 
encouraged the 52 Maori chiefs to sign the Declaration of Independence of New Zealand. Although this document had little effect at that time, it indicates that it was impossible for the Maori chiefs to give up their mana. Nevertheless, James pioneered to get the Maori chiefs together and sign documents to express the common will of Maori tribes. This document laid foundation for treaty of Waitangi.

\section{NEGOTIATIONS BETWEEN MAORIS AND EUROPEANS \\ Background of the Treaty of Waitangi(1840)}

In the later part of 1830s, the sovereignty of Queen Victoria intended to get the land from Maori tribes. They had foreseen that occupying in force is bound to cause the violent defenses. So in the middle of 1839, they draw a document whose content was the cession of the land from Maori to the Crown. They claimed that the new settlers from European have bought vast lands and the Maori tribes' sovereignty was "little more than nominal". The British protection had brought great benefit which cannot be maintained by the natives. This document was the famous Treaty of Waitangi.

The British tried to convince Most of the Maori chiefs of the belief that the Treaty of Waitangi would bring much more economic profits and enhance their mana. As a result, about 500 chiefs signed the treaty according to their own will which was misled by the British people. After the meeting, they found that the English treaty and the Maori treaty are different.

\section{Misinterpretation of the Treaty of Waitangi and Its Consequences}

Treaty of Waitangi is the agreement between Maori and Queen of England, which was first signed by captain Hobson, chiefs of Confederation of United Tribes of New Zealand and the independent chiefs who were not members of the confederation on 6 February 1840. This treaty is to transfer the sovereignty of Maori people's land to the Queen of England and to guarantee that the Maori would gain the better protection from the Crown.

The Treaty was first drafted by William Hobson, James Busby and some other British people. The draft was written in English. In order to make it understood by Maori chiefs, they asked Missionary Henry Williams and his son Edward who both were familiar with Maori language to translate the draft. But the translation did not go with the original English text.

As a result of the translation process, the treaty in Maori version and that in English in fact are two different treaties: te Tiriti o Waitangi (the Maori version) and the Treaty of Waitangi (the English version). "The purpose of the treaty was the cession of chiefly authority to Queen Victoria, but the Maori translation of the treaty did not make this clear." So the Maori people feel that they were deceived. The differences between the two texts have a far-reaching influence on the New Zealand society. Even nowadays, this is still a controversial issue.

From the preamble, the emphases of the two versions have already been different. In the English preamble, "Civil Government" was referred to protect Maori "rights and property"; The Maori preamble is more brief and promises the Queen Victoria would preserve to Maori their "chieftainship and their land". (Janine Hayward, 2004:156-157). "Rights" and "chieftainship" is not equal. Keeping mana (sovereignty) for Maori chief is the most important, but "rights" in fact do not include keeping mana.

Take for example the first article which is about the cession of sovereignty over New Zealand to the Queen Victoria. However, the Maori version does not mention this as its purpose was blurred by the translators. The word sovereignty (mana in Maori) did not appear in the Maori treaty. Instead of mana, they used word Kawanatanga which means governance in the Maori 
version which is entirely differene from the word "sovereignty". It was unfair for the Maori people as they had no idea what they were signing. Maoris thought they would just give up their governance of their land, but from the version of English, they would give up their mana, their chieftainship or their sovereignty over their land. If they had figure out what they would hand over to the Crown before they signed, they would never have done that.

The second article is about the protection from the Queen. In the Maori translation, "possession" was translated to "tino rangatiratanga" which contain far more meaning than "possession". Actually, "tino rangatiratanga" is "a better approximation to sovereignty than kawanatanga" (Orange, 1987:41). In 1835 Declaration of Independence of New Zealand, "rangatiratanga" was used to refer to the independence of New Zealand. Therefore, the chiefs understood the treaty as a confirmation of their own sovereignty for a limited concession of power in kawanatanga (Walker, 1990:93). "Whatever Williams intended, it is clear that the treaty text, in using kawanatanga and rangatiratanga, did not spell out the implications of British annexation" (Orange, 1987:42). Obviously, difference in understanding the language in part resulted in the loss of sovereignty for the Maoris.

The third article which was the least disputed was about the Crown protecting all the Maori people in New Zealand and gives them all rights equal to the new settlers from England. The two versions of this part were in concord. In addition, the forth article was only in the Maori version which said the Queen would protect the religion freedom of Maoris.

Some people claim that the defects of the translation may result from the translation skill of William and his advisers. But this is not a good excuse. As everybody knows, the translation was done by two missionary who had contacted with Maori for a long time and had been familiar with the Maori language and culture. Even if they did not know how to comprehend the key word "Kawanatanga" and "rangatiratanga" clearly, they could still consult their Maori friends to figure it out but they did not do that. Thus it can be seen that William's group gained an advantages over Maoris by playing word tricks.

It's clear that the Treaty of Waitangi indicates the beginning of the bringing New Zealand under subjugation of the British Empire. "Colonies had been particular forms of imperialism, created during the tide of western European expansion into other continents and oceans from the 16th century onwards."(Adam\& Jessica, 1999:105). The expansions of colonialism expand to every corner of the world, from Asia to Africa, from America to Oceania. Actually this period is the most splendid age of Britain Empire which was called sun-never-set empire. The imperialism of Britain was expanded all over the world. For seizing more resources to get much more economic interests, British take various methods to get sovereignty of the other country or races. Coincidentally, in the same year of signing Treaty of Waitangi, Britain Empire first started the Opium War which is the first invasive war which marked the beginning of Modern History of China. After that war, Britain also grabbed many treasures from China. However, the situation of China is far more complicated. It is hard to establish a completed colony there, whereas the only block to establish a colony in New Zealand is Maori tribes. What's more, Maori people actually depend much on them to get economic benefits. Therefore, capturing New Zealand was an inevitable trend.

\section{CONCLUSION}

In conclusion, Treaty of Waitangi is a monument in the history of New Zealand. In fact, it is a symbol of the beginning of the combination between White people and Maoris. Although there are still some points in dispute, we cannot deny that the treaty have brought New Zealand 
valuable peace and stability for the following years after 1840. Therefore, New Zealand people should never forget the ancestors who made contributions to reach the agreement in 1840 .

\section{References}

Adam.K and Jessica.K. The Social Science Encyclopaedia. 2nd ed. London: Routledge, 1999.

Erik Olssen and Michael P. J. Reilly. “Te tutakitanga o nga ao e rua - Early Contacts between Two Worlds.” Ki Te Whaiao - An Introduction to Maori Culture and Society. Ed: Tānia M. Ka'ai, et al. Auckland: Pearson Education New Zealand Limited, 2004.

James H. Liu., et al. "Introduction: Constructing New Zealand Identities." New Zealand Identities: departures and destinations. Ed. James H. Liu., et al. Wellington: Victoria University Press, 2005.

James Ritchie. Becoming Bicultural. Wellington: Huia publishers \& Daphne Brasell Association Press, 1992.

Janine Hayward. “Te Tirti o Waitangi - The Treaty of Waitangi." Ki Te Whaiao - An Introduction to Maori Culture and Society. Ed: Tānia M. Ka'ai, et al. Auckland: Pearson Education New Zealand Limited, 2004.

Michael P. J. Reilly. "Te timatanga mai o nga atua - Creation Narrative." Ki Te Whaiao - An Introduction to Maori Culture and Society. Ed: Tānia M. Ka'ai, et al. Auckland: Pearson Education New Zealand Limited, 2004.

The History Group of the New Zealand Ministry for Culture and Heritage. Read the Treaty. 1 Fed. 2017 <https://nzhistory.govt.nz/politics/treaty/read-the-treaty/english-text >.

The History Group of the New Zealand Ministry for Culture and Heritage. Frontier of chaos? - Maori-Pakeha contact pre-1840. 5 Aug. 2014 <http://www.nzhistory.net.nz/culture/pre-1840-contact/frontier-of-chaos>.

The History Group of the New Zealand Ministry for Culture and Heritage. Maori values and practices - a frontier of chaos? 20 Dec. 2012 <http://www.nzhistory.net.nz/culture/frontier-of-chaos/maori-values>

The History Group of the New Zealand Ministry for Culture and Heritage. Sealers and whalers - pre-1840 contact. 19 Sep. 2014 <http://www.nzhistory.net.nz/culture/pre-1840-contact/sealers-and-whalers>

Orange Claudia. The Treaty of Waitangi. Wellington: Allen and Unwin, 1987.

Walker Ranginui. Ka Whawhai Tonu Matou: Struggle without End. Auckland: Penguin Books, 1990. 